\section{SILVER JUBILEE - 25 YEARS OF PARTNERSHIP, WORK AND ACHIEVEMENTS. (UNIVERSITY OF BOLOGNA, PUC MINAS, AVSI)}

João Francisco de Abreu'

As we celebrate 25 years of partnership, we remember the first visit of Prof. Mingucci ${ }^{2}$ to PUC Minas (Pontifical Catholic University of Minas Gerais). Together with Father Magela ${ }^{3}$, Father Antoniazzi ${ }^{4}$ and Professor Abreu ${ }^{5}$, they started to design the basis of that partnership in mid-1984.

Some achievements were relevant. In 1986, we held the first seminar in Bologna, with the support of the Belo Horizonte Town Hall and AVSI, preparing for the great Projeto Pró-Favela (Pro-Slum Project), in district $1^{\circ}$ de Maio, in Belo Horizonte. The UEE approved the Project and the 1st Regional Urban Planning Program, offered by PUC Minas and the University of Bologna in 1988-9. It was a wonderful experience, with the full-time participation of students from PUC Minas, including intensive training in Italian Language and computer bases for analytical cartography.

Besides the work carried out by Brazilian professors from PUC Minas and UFMG (Federal University of Minas Gerais), many professors from Italian universities came to Brazil to give courses divided into modules.

The Program ended with the students and Brazilian professors' trip to Bologna. The presentation of monographs took place during a seminar in Belo Horizonte the following year, with Italian professors and some guests from American universities.

Those initial contacts gave fruit: a second program took place, following the same framework; a laboratory of geo-processing for slum mapping was implemented; and the Program of Architecture and Urbanism of PUC Minas was created. Besides, there were periodical trips of Italian professors to Brazil and of Brazilian professors to Italy.

One cannot forget the fundamental participation of the University of Bologna in partnerships in the urban area, with professors Roberto Mingucci and Carlo Monti, besides the serious hard work of AVSI, through its president Arturo Alberti and the Michelinnis (Ana and Lívio), who dedicated many years of their life to the cause of slums in Brazil.

Another relevant participation was that of Prof. Piero Secondini and his group, in a state-of-the-art academic and scientific exchange with Prof. João Francisco de Abreu that lasted for years. Prof. Aurélio Muzzarelli became visiting professor of the Master's Degree and Doctorate in Spatial Information Handling of PUC Minas.
1. Dean of Research and Graduate Studies of PUC Minas.
2. Professor of the University of Bologna in the field of Architecture and Urban Planning
3. Dean of Extension Activities of PUC Minas.
4. Professor of PUC Minas in the field of Theology and Philosophy
5. Coordinator of International Relations of PUC Minas. 


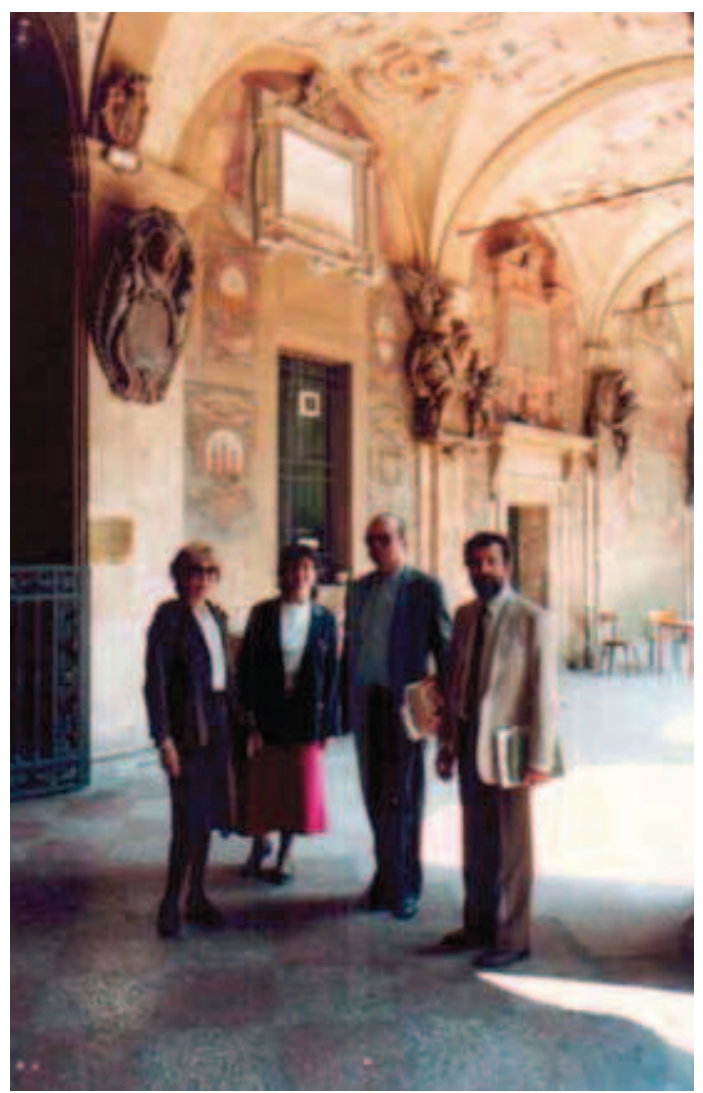

Figure 1 1986 - University of Bologna.

Father Geraldo Magela Teixeira -

Chancellor of PUC Minas. Prof. João

Francisco de Abreu - Coordinator of

International Relations of PUC Minas.

Members of AVSI / University of

Bologna.
This partnership, which now completes 25 years, has been a harmonious and highly productive experience, and we hope it goes on vibrant, active and constant.

In the words of Brazilian novelist Guimarães Rosa: "I dispatched my horse at a run with ten legs, and arrived at the rocky wall under the last rays of twilight".

Let us all meet again in the Gold Jubilee.

\section{Professors, among others, of the Program of Regional Urban Planning}

- Alberto Corlaita (UNIBO)

- Ana Adelina Lins (PUC Minas)

- Astrid Masetti Lobo Costa (PUC Minas)

- Carlo Monti (UNIBO)

- Giorgio Praderio (UNIBO)

- Giuseppe Folloni (Università di Trento)

- Ivo Amparato (AVSI)

- João Francisco de Abreu (PUC Minas)

- Lan Franco Senn (Università di Milano)

- Maria Antonieta Crippa (Politecnico di Milano)

- Piero Secondinni (UNIBO)

- Roberto Mingucci (UNIBO)

- Roberto Rizzini (Università di Milano)

- Arturo Alberti (AVSI)

- Livio Michelini (AVSI)

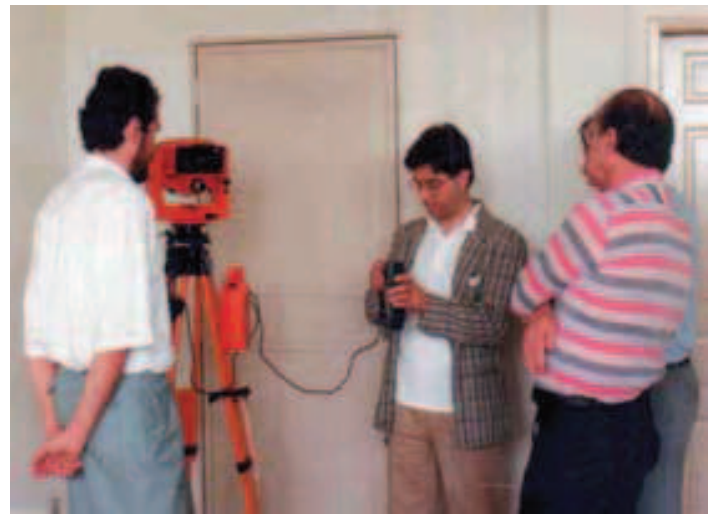

Figure 2 • - Laboratory of

Geoprocessing (Belo Horizonte). Father Geraldo Magela Teixeira - Chancellor of PUC Minas. Prof. Roberto Mingucci Professor of the University of Bologna. Prof. Lívio Michellini - Coordinator of AVSI in Belo Horizonte. 


\section{References}

ABREU, J. F. Relatório Técnico N\# 19/1990. Curso de Planejamento Urbano Regional, PUC Minas/AVSI/UNIBO, Belo Horizonte: Fumarc, 1990
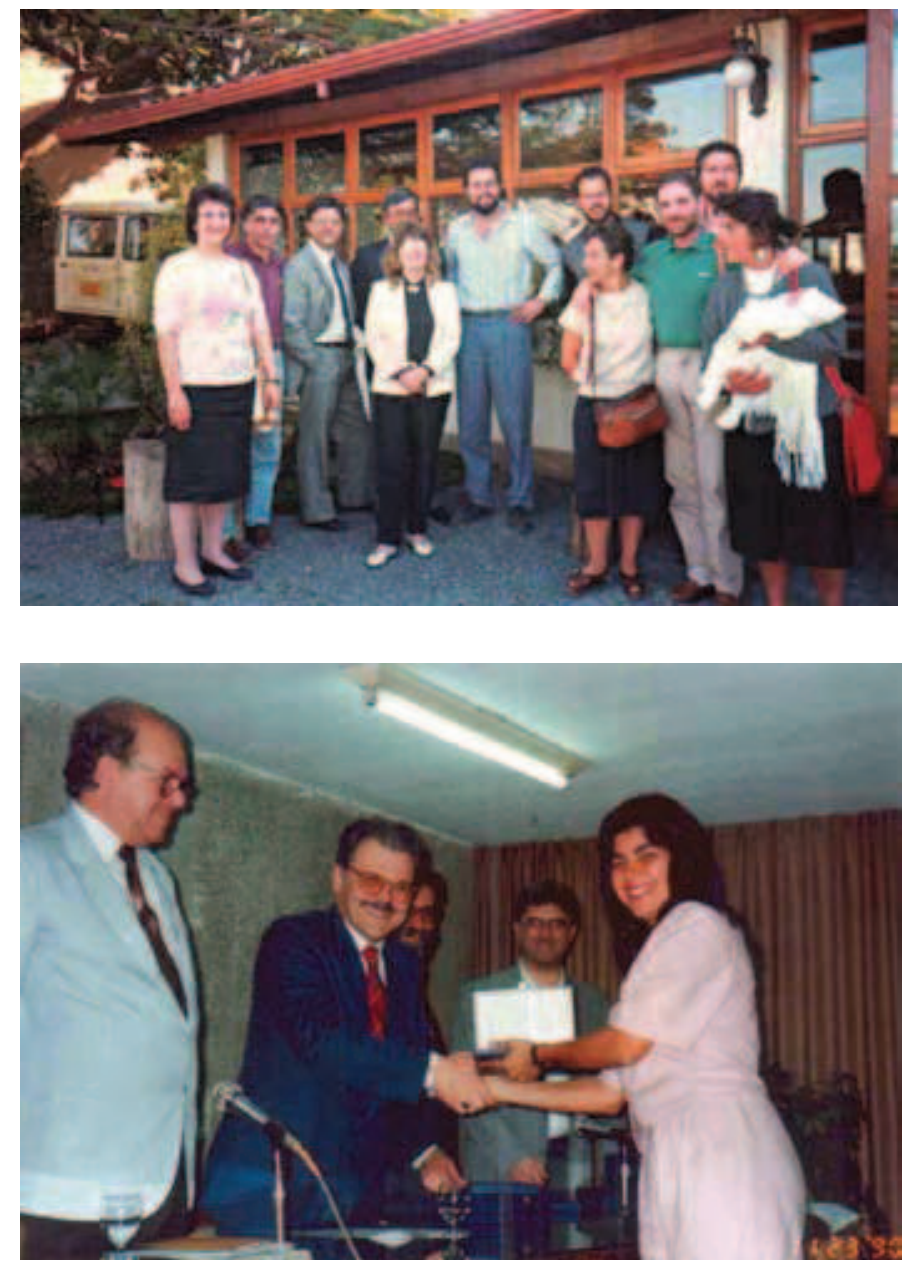

Figure 3 • - Gathering. AVSI / PUC Minas / University of Bologna. (Belo Horizonte / 1988).

Figure 4 - Granting Certificates of the 1st Program of Regional Urban Planning (Belo Horizonte - 1990). 